\title{
Diffusion of Covid-19 in the Northern Metropolis in Northeast Brazil: territorial dynamics and risks associated with Social Vulnerability
}

\author{
Davis Pereira de Paula1 \\ David Hélio Miranda de Medeiros ${ }^{2}$ \\ Eduardo Lacerda Barros ${ }^{3}$ \\ Renan Gonçalves Pinheiro Guerra 4 \\ Jader de Oliveira Santos 5 \\ João Sérgio Queiroz Lima6 \\ Rafaela Martins Leite Monteiro ${ }^{\text {(id }}$
}

Keywords:

Coronavirus

SARS CoV-2

Pandemic

\begin{abstract}
Throughout history, humankind has lived through many crises arising from pandemics, and it is currently in the midst of one. Coronavirus disease, caused by the severe acute respiratory syndrome coronavirus 2 , is causing serious problems related to public health and socioeconomic status across the globe. Having started in Asia, the disease has already reached Europe, Africa, and more recently the Americas; hence, it is necessary to understand the context in which it spreads in regions that carry high risks associated with social vulnerability, as in the case of Latin America. Brazil is the South American country most affected by the pandemic - its first case was confirmed at the end of February 2020, and in less than two months, its total number of cases has already crossed 25,000. Among its worst-hit states, Ceará in Northeast Brazil worries health agencies as there have already been more than 2,000 cases in the 30 days of the outbreak in the state. Even more worrying is its capital Fortaleza, which has become the epicenter of the spread of the disease in Ceará, accounting for $86.5 \%$ cases and $67 \%$ deaths in the state-95\% of the neighborhoods in Fortaleza have confirmed cases of the disease. An aspect that particularly causes concern is the disease's diffusion, from neighborhoods with the highest family income to those with the lowest, directly affecting the socially vulnerable populations in territories with a majority of precarious settlements; in Fortaleza, favelas are the main type of precarious settlements (73.6\%). The analyses presented as part of this research can assist in identifying priority areas for state intervention through family assistance resources.
\end{abstract}

1 Universidade Estadual do Ceará - UECE. davispp@gmail.com

2 Universidade Estadual do Ceará - UECE. davidhmmedeiros@gmail.com

${ }^{3}$ Universidade Federal do Ceará - UFC/LABOMAR/UFC. eduardo.lgco@gmail.com

${ }^{4}$ Secretaria do Meio Ambiente - SEMA/CEARÁ. renan.lgco@gmail.com

5 Universidade Federal do Ceará - UFC. jader.santos@gmail.com

${ }^{6}$ Universidade Federal do Ceará - UFC. joaosergio1980@gmail.com

${ }^{7}$ Instituto de Pesquisa e Estratégia Econômica do Ceará - IPECE. rafaelamlmonteiro@gmail.com 


\section{INTRODUCTION}

History is rife with global crisis, like the ongoing coronavirus disease (COVID-19) (DECAPPRIO et al., 2020; FISMAN et al., 2020). The 20th century saw three major global epidemiological outbreaks of influenza-H1N1 or the Spanish flu in 1918, H2N2 or the Asian flu in 1957, and H3N2 or the Hong Kong flu in 1968. These pandemics, however, did not show periodicity and pattern, hindering epidemiological control (MILLS; ROBINS; LIPSITCH, 2004; KILBOURNE, 2006; HSIEH et al., 2006; CARTER; SAUNDERS, 2007; LAYNE; MONTO; TAUBENBERGER, 2009).

COVID-19 is an infectious disease caused by the severe acute respiratory syndrome coronavirus 2 (SARS-CoV-2). Its outbreak occurred at the end of 2019 in China, in the city of Wuhan, Hubei province (WHO, 2020a). In South America, which has a population of 640 million, the first case was detected in Brazil on February 25, 2020, in São Paulo (RODRIGUEZMORALES et al., 2020).

According to data from the World Health Organization (WHO), as of April 14, 2020, the focal territories of registered cases of the disease worldwide are concentrated in the United States (576,695), Spain (169,510), Italy $(159,516)$, France $(136,779)$, Germany $(128,166)$, the United Kingdom (88,621), and China (82,160). Considering this, on March 11, 2020, the WHO declared COVID-19 a pandemic.

According to Coelho et al. (2020), on March 21, 2020, COVID-19 cases were recorded in 184 countries, with more than 266,000 of those confirmed and 11,184 deaths. On April 2, 2020, the number of cases worldwide reached 1 million and deaths 51,000, over the 93 days since the outbreak. In the third week of April 2020, the number of confirmed cases reached almost 2 million and deaths 450,000 (WHO, 2020b). What is particularly alarming in these numbers is the second million getting infected in a matter of two weeks, demonstrating the speed and spread of the contagion.

Until April 14, 2020, Brazil had more than 25,000 confirmed cases, as informed by the Ministry of Health (MS, in Portuguese). After the start of the spread of the disease in the country, on March 16, 2020, the Government of Ceará, through State Decree $\mathrm{n}^{\circ} 33.510$, declared a health emergency and implemented measures to deal with the contagion; on March 19, 2020, after 24 confirmed cases, it intensified the measures, including enforcement of quarantine and social distancing through State Decree No.

\subsection{9 (CEARÁ, 2020a; CEARÁ, 2020b)}

On March 20, 2020, the MS announced the occurrence of community transmission of SARSCoV-2 across the national territory. In an official statement on March 26, 2020, it also declared that in Ceará, the outbreak started from Fortaleza - a case of imported contamination with the Fortaleza International Airport being the diffusion medium of the virus in the city. Fortaleza is an important air hub for national (a direct and indirect destination for all Brazilian cities) and international integration (Europe and South and North Americas, especially the US).

Fortaleza is among the cities hit the hardest by the COVID-19 pandemic in South America, which is worrying considering it is the 10thlargest South American metropolis and the fifthlargest Brazilian city, with a population of over 2.6 million (IBGE, 2019). Thus, this research contends that Fortaleza, as the main city in Northeast Brazil with a comprehensive transport network, is among the country's most affected territories by SARS-CoV-2. Therefore, the research objective is to evaluate the territorialization of COVID-19 in Fortaleza and its propensity to spread to the most socially vulnerable neighborhoods.

\section{THE CITY OF FORTALEZA AND ITS GEOLOCATION}

Fortaleza has $312,407 \mathrm{~km}^{2}$ and an estimated population of $2,669,342$ as of 2019 , accounting for $20 \%$ of the total population of the State of Ceará; its demographic density is 7,786 inhabitants $/ \mathrm{km}^{2}$, with an average Human Development Index (HDI) of 0.754 (IBGE, 2019). Fortaleza is the main urban center in Ceará, comprising 19 municipalities in its metropolitan region; it has the Atlantic Ocean to its north, the municipalities of Maracanaú, Itaitinga, and Pacatuba to its south, Eusébio and Aquiraz to its west, and Caucaia to its east.

It is the fifth-largest Brazilian metropolis, with accelerated growth and high population density especially in its peripheral zone (MARQUES; LIMA; SANTOS, 2020). In the early years of the 21st century, the city was consolidated as the main urban center of Northeast Brazil (LIMA; SANTOS, 2018). According to the 2010 demographic census by the Brazilian Institute of Geography and Statistics (IBGE), Fortaleza has approximately 780,456 households (IBGE, 2011).

In its current political and administrative structure, it has 121 neighborhoods, 39 
subdistricts, and 12 districts, organized by the communities' historical, cultural, and geographical characteristics (FORTALEZA, 2020a). The Municipality of Fortaleza officially divides the city into seven regions, managed by Executive Secretaries, ranging from I to VI (Fig. 1, Table.1), and also counts on the Secretariat of the Center of Fortaleza (SERCEFOR).

Figure. 1. Geolocation of Fortaleza in Ceará, with its division by regional secretaries and distribution

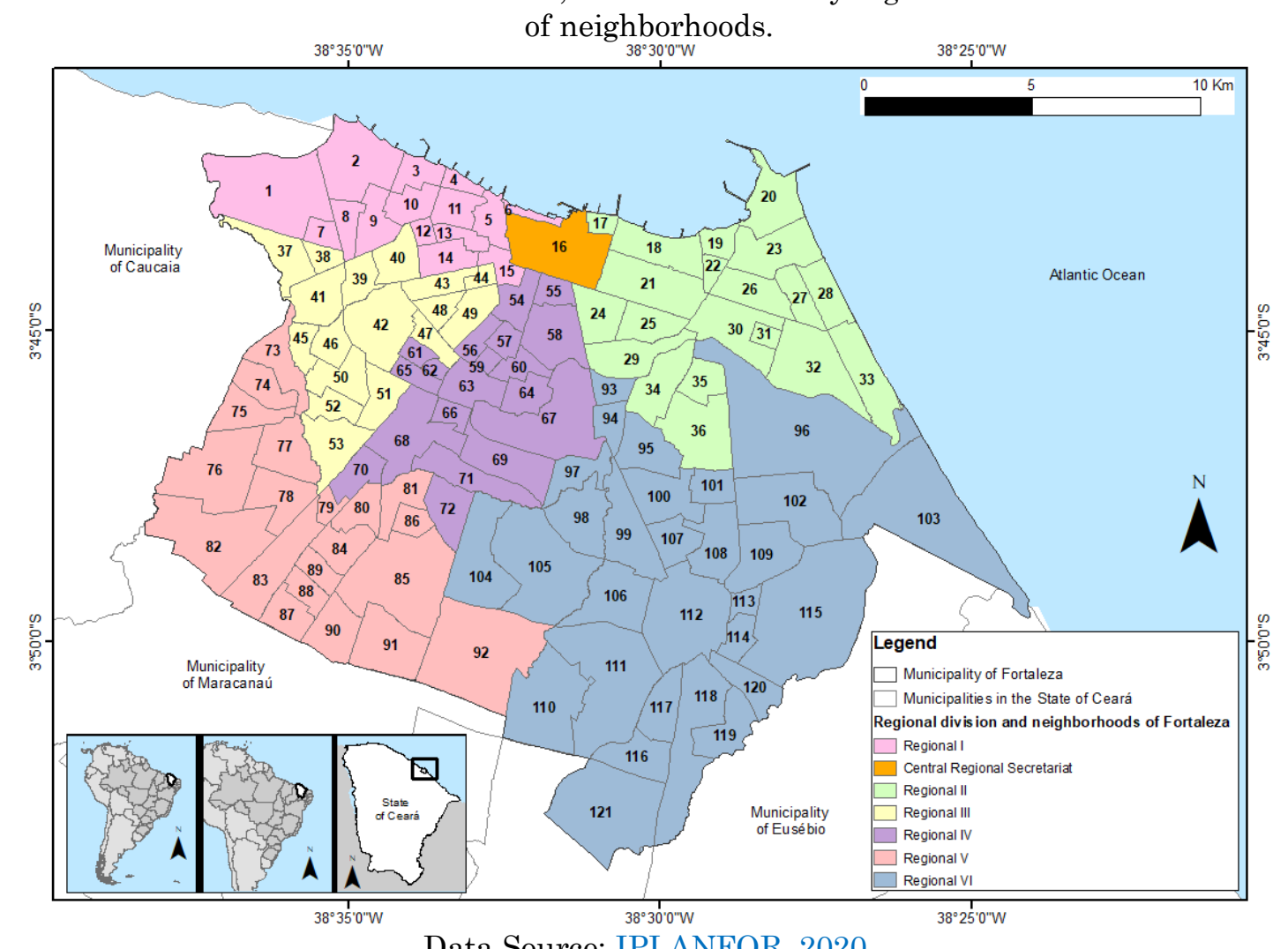

Data Source: IPLANFOR, 2020.

\section{THE COVID-19 PANDEMIC IN CEARÁ AND ITS TERRITORIALIZATION IN FORTALEZA}

The records and information used in the monitoring of an investigation into COVID-19 cases in Brazil and Ceará applied herein were acquired from MS (Federal Government), State Health Secretariat - SESA (Ceará State Government), and Fortaleza Municipal Health Secretariat - SMS (Fortaleza City Hall). The updates for Ceará were recorded using information from the IntegraSUS Ceará Digital Platform

For analyzing the situation surrounding the pandemic in Ceará and its territorialization in Fortaleza and its neighborhoods, records registered until the first three days in the fifth week of the outbreak-from March 15 to April
14, 2020-were considered; the end date corresponds to the day of publication of the most current epidemiological bulletin for Fortaleza, the focus of this research (FORTALEZA, 2020b; FORTALEZA, 2020c; FORTALEZA, 2020d).

\section{Ceará in the national and regional contexts vis-à-vis COVID-19 cases}

The number of confirmed cases and deaths due to COVID-19 worldwide and in Brazil is growing by the day. However, a much bigger concern is the rising cases within socially vulnerable communities that lack basic healthcare and urban infrastructure, as is the case in the peripheral areas of developing countries and especially in the peripheries of the urban agglomerations in Northeast Brazil. 
Table. 2. Regional secretaries and distribution of neighborhoods.

\begin{tabular}{|c|c|c|c|c|c|c|c|}
\hline \multicolumn{8}{|c|}{ NEIGHBORHOOD DIVISIONS IN THE CITY OF FORTALEZA } \\
\hline \multicolumn{4}{|c|}{ REGIONAL I (NEIGHBORHOODS) } & \multicolumn{4}{|c|}{ REGIONAL IV (NEIGHBORHOODS) } \\
\hline 1 & Vila Velha & 9 & Floresta & 54 & Benfica & 64 & Vila União \\
\hline 2 & Barra do Ceará & 10 & Álvaro Weyne & 55 & José Bonifácio & 65 & Demócrito Rocha \\
\hline 3 & Cristo Redentor & 11 & Carlito Pamplona & 56 & Damas & 66 & Itaoca \\
\hline 4 & Pirambú & 12 & Ellery & 57 & Jardim América & 67 & Aeroporto \\
\hline 5 & Jacarecanga & 13 & Monte Castelo & 58 & Fátima & 68 & Parangaba \\
\hline 6 & Moura Brasil & 14 & São Gerardo & 59 & Bom Futuro & 69 & Serrinha \\
\hline 7 & $\begin{array}{c}\text { Jardim } \\
\text { Guanabara }\end{array}$ & 15 & Farias Brito & 60 & Parreão & 70 & Vila Peri \\
\hline \multirow[t]{2}{*}{8} & Jardim Iracema & & & 61 & Panamericano & 71 & Itaperi \\
\hline & $\begin{array}{r}\text { CENTRAL REGI } \\
\text { (NEIGH }\end{array}$ & $\begin{array}{l}\text { NAI } \\
\text { ORH }\end{array}$ & $\begin{array}{l}\text { SECRETARIAT } \\
\text { OODS) }\end{array}$ & 62 & Couto Fernandes & 72 & Dendê \\
\hline 16 & & Cen & & 63 & Montese & & \\
\hline \multicolumn{4}{|c|}{ REGIONAL II (NEIGHBORHOODS) } & \multicolumn{4}{|c|}{ REGIONAL V (NEIGHBORHOODS) } \\
\hline 17 & $\begin{array}{l}\text { Praia de } \\
\text { Iracema }\end{array}$ & 27 & De Lourdes & 73 & Genibaú & 83 & Canindezinho \\
\hline 18 & Mireles & 28 & Praia do Futuro I & 74 & Conjunto Ceará I & 84 & Novo Modunbim \\
\hline 19 & Mucuripe & 29 & Tauape & 75 & Conjunto Ceará II & 85 & Mondubim \\
\hline 20 & Cais do Porto & 30 & Cocó & 76 & Granja Lisboa & 86 & Jardim Cearense \\
\hline 21 & Aldeota & 31 & Cidade 2000 & 77 & Granja Portugal & 87 & Parque Presidente Vargas \\
\hline 22 & Varjota & 32 & Manuel Dias Branco & 78 & Bom Jardim & 88 & Parque Santa Rosa \\
\hline 23 & Vicente Pinzon & 33 & Praia do Futuro II & 79 & Parque São José & 89 & Conjunto Esperança \\
\hline 24 & Joaquim Távora & 34 & Salinas & 80 & Manoel Sátiro & 90 & Aracapé \\
\hline 25 & Dionísio Torres & 35 & Guararapes & 81 & Maraponga & 91 & Planalto Ayrton Senna \\
\hline 26 & Papicu & 36 & $\begin{array}{l}\text { Eng. Luciano } \\
\text { Cavalcante }\end{array}$ & 82 & Siqueira & 92 & Prefeito José Walter \\
\hline \multicolumn{4}{|c|}{ REGIONAL III (NEIGHBORHOODS) } & \multicolumn{4}{|c|}{ REGIONAL VI (NEIGHBORHOODS) } \\
\hline 37 & Quintino Cunha & 46 & Dom Lustosa & 93 & Alto da Balança & 108 & Cambeba \\
\hline 38 & Olavo Oliveira & 47 & Bela Vista & 94 & Aerolândia & 109 & José de Alencar \\
\hline 39 & Padra Andrade & 48 & Amadeu Furtado & 95 & Jardim das Oliveiras & 110 & Conjunto Palmeiras \\
\hline 40 & $\begin{array}{l}\text { Presidente } \\
\text { Kennedy }\end{array}$ & 49 & Rodolfo Teófilo & 96 & Edson Queiroz & 111 & Jagurussu \\
\hline 41 & $\begin{array}{l}\text { Antônio } \\
\text { Bezerra }\end{array}$ & 50 & Henrique Jorge & 97 & Dias Macedo & 112 & Messejana \\
\hline 42 & Pici & 51 & Jóquei Clube & 98 & Boa Vista/Castelão & 113 & Curió \\
\hline 43 & Parquelândia & 52 & João XXVIII & 99 & Cajazeiras & 114 & Guajeru \\
\hline 44 & Parque Araxá & 53 & Bonsucesso & 100 & Cidade dos Funcionários & 115 & Lagoa Redonda \\
\hline \multirow[t]{7}{*}{45} & Autran Nunes & & & 101 & Parque Manibura & 116 & Ancuri \\
\hline & & & & 102 & Sapiranga Coité & 117 & Parque Santa Maria \\
\hline & & & & 103 & Sabiaguaba & 118 & Paupina \\
\hline & & & & 104 & Parque Dois Irmãos & 119 & São Bento \\
\hline & & & & 105 & Passará & 120 & Coaçu \\
\hline & & & & 106 & Barroso & 121 & Pedras \\
\hline & & & & 107 & Parque Iracema & & \\
\hline
\end{tabular}

Source: IPLANFOR, 2020.

Until April 14, 2020, the total number of cases in Brazil and Ceará was 25,262 and 2,075, respectively (Fig. 2), with Ceará accounting for $8.2 \%$ of all COVID-19 cases recorded in Brazil. On a national scale, Ceará has the third-largest number of confirmed cases in the country, behind São Paulo $(9,371)$ and Rio de Janeiro
$(3,410)$; however, if one considers the population infection rate, the situation is worse in this state. Based on the analysis of this data, Fortaleza ranks first among capital cities vis-à-vis the rate of incidence (1 million inhabitants) (BRASIL, 2020a). 
Figure. 2. Confirmed cases of COVID-19 in Brazil and Ceará until April 14, 2020. The graph shows the

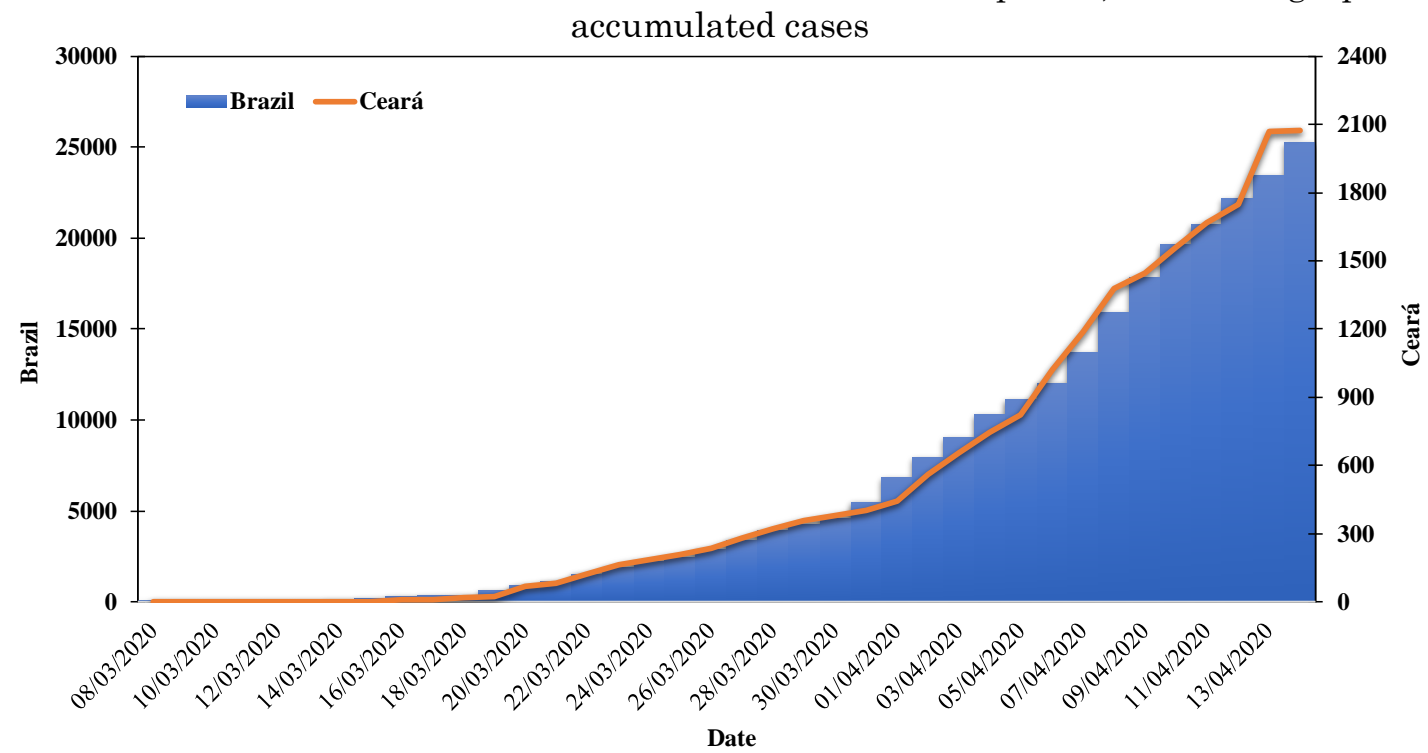

Data: Epidemiological bulletins from MS and SESA, updated on April 14, 2020 at $14 \mathrm{~h}$ by MS and 17h by SESA, subject to revision.

Ceará ranks first in the number of confirmed cases in Northeast Brazil, accounting for 39.5\% of the total, and second in the number of deaths, accounting for $32.9 \%$ of the total. In this state, as in most of Brazil, both these numbers are rising every hour. Silva and Muniz (2020) have called it a speeding growth. For example, in 21 days
(March 15 to April 4, the first three weeks), 744 cases and 44 deaths were recorded in Ceará, while in just 10 days (April 5 to 14, the fourth and fifth weeks), 1,331 new cases (a 179\% increase) and 78 deaths (a $177.2 \%$ increase) were recorded (Fig. 3).

Figure. 3. Accumulated number of confirmed cases and deaths due to COVID-19 in Ceará until April $11,2020$.

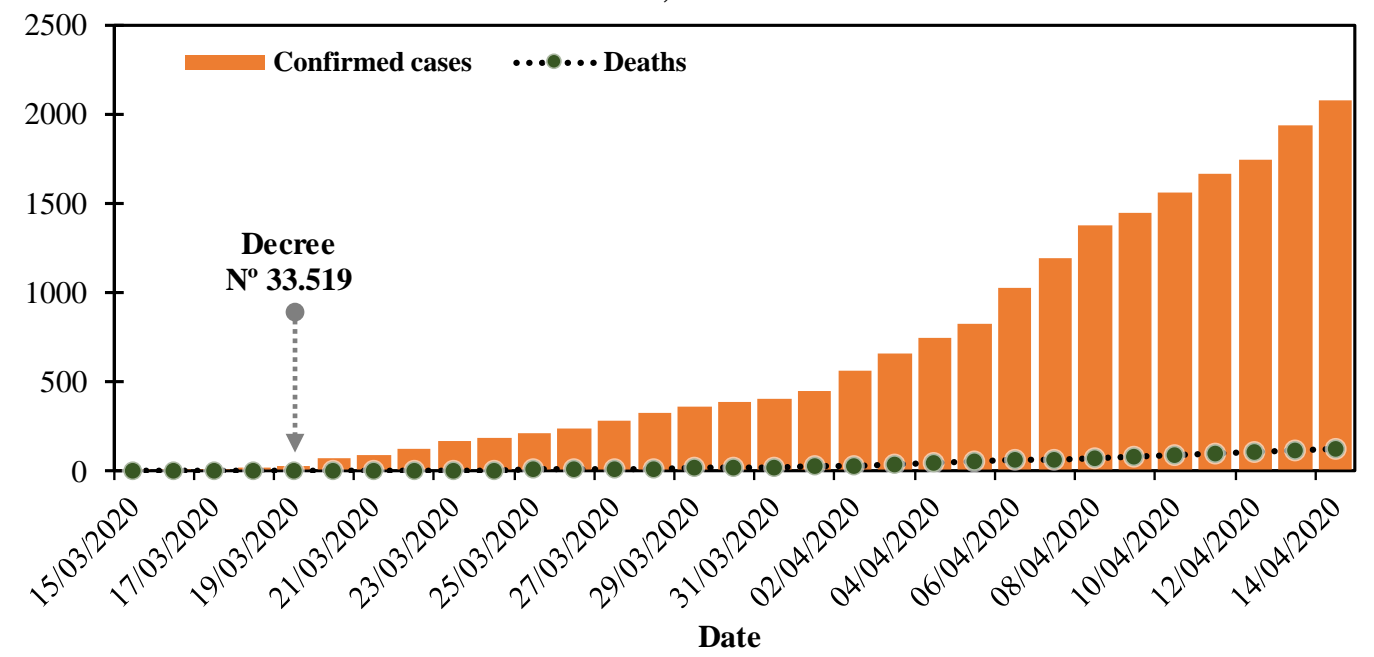

Data: SESA epidemiological bulletins.

The period from the fourth to the fifth week of the outbreak in Ceará has been the most critical concerning the detection of new cases-a one-day record was created on April 4, 2020, with 201 new cases (Fig. 4A). In the fifth week, Ceará recorded an average of 136 new cases daily. Compared with the first week, this is an increase of 1,131\% (Figs. 4B and 4C). 
Figure. 4. Increase in new COVID-19 cases in Ceará over the first four weeks of the outbreak. 4a) Daily increment in cases; 4b) Average number of new cases; 4c) Percentage growth in the number of cases.

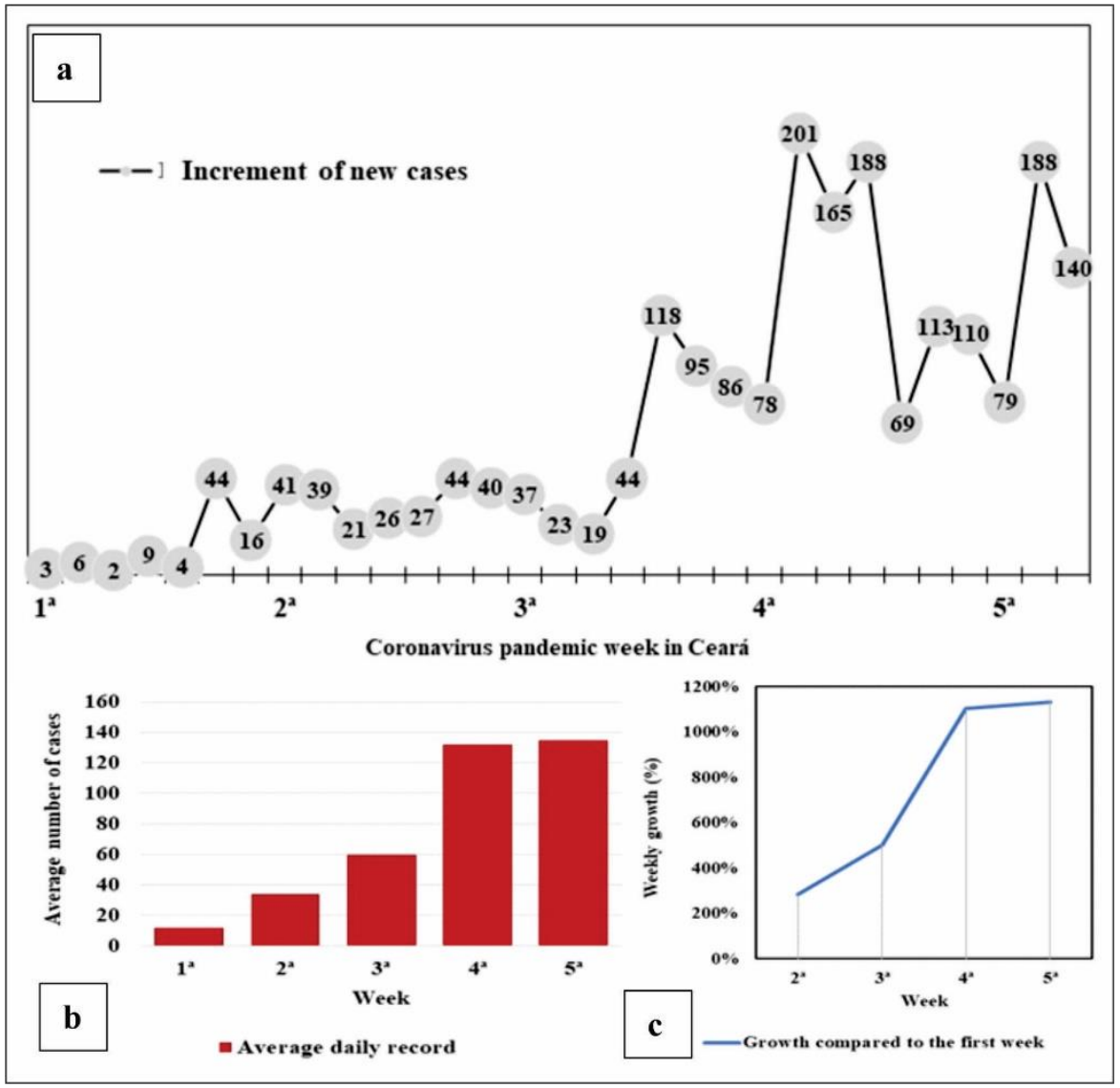

Data: Epidemiological bulletins from MS and SESA.

On April 14, 2020, the rate of new cases was 64.5 per day, or 2.8 per hour. Now, considering only part of the fifth week, the average daily increase has been 135 new cases, or 5.6 per hour (Fig. 5). Thus, up to the fifth week of the pandemic in Ceará, cases were detected in 73 of the 184 municipalities, with 38 cases still without municipal indication.

\section{Spatial diffusion of COVID-19 in Fortaleza}

All COVID-19 case records in Fortaleza have been released on SMS and SESA digital platforms. However, the update times are different for each platform, leading to a mismatch in the departments' time of publication and, consequently, in the number of records.

For a general analysis of confirmed cases and deaths in Fortaleza, statistics from the SESA Transparency Platform (IntegraSUS) were used, as these are updated several times during the day. For the analysis of records by neighborhoods in the city, information from epidemiological bulletins released by the Municipality of Fortaleza through its digital platform was used, as details on this are not available on IntegraSUS.

The spread of SARS-CoV-2 in Ceará involves Fortaleza as one of the main areas for the rising number of cases and deaths in Brazil. In other words, it is the epicenter of the pandemic in Ceará with 2,030 confirmed cases and 82 deaths until April 14, 2020 (CEARÁ, 2020c).

Nationally, Fortaleza is the capital with the highest incidence rate of COVID-19 cases-the incidence coefficient (per 100,000 inhabitants) released by MS (BRASIL, 2020b) puts the city at the top $(34.7 / 1,000,000)$ in Brazil (Fig. 6); its incidence coefficient is $50 \%$ higher than the national estimate, resulting in the situation there being classified as an emergency owing to the uncontrolled acceleration of the spread of the disease in its fifth week (BRASIL, 2020b). 
Figure. 5. Variation in the number of new COVID-19 cases per hour in Ceará over the first month of the outbreak.

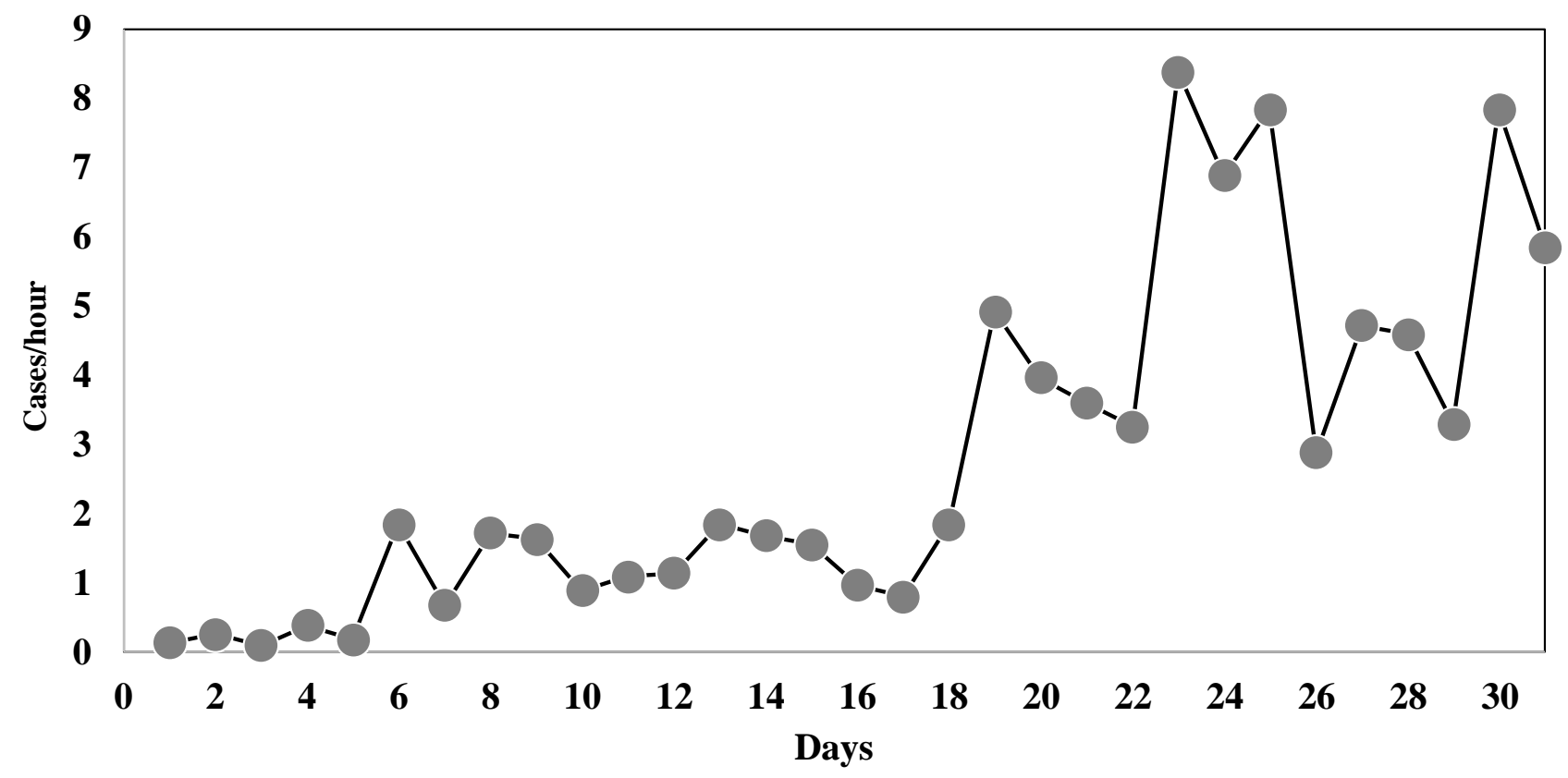

Data: SESA epidemiological bulletins.

Figure. 6. Incidence coefficient (per 100,000 inhabitants) of each capital released by the Ministry of Health, considering the IBGE projection for 2020.

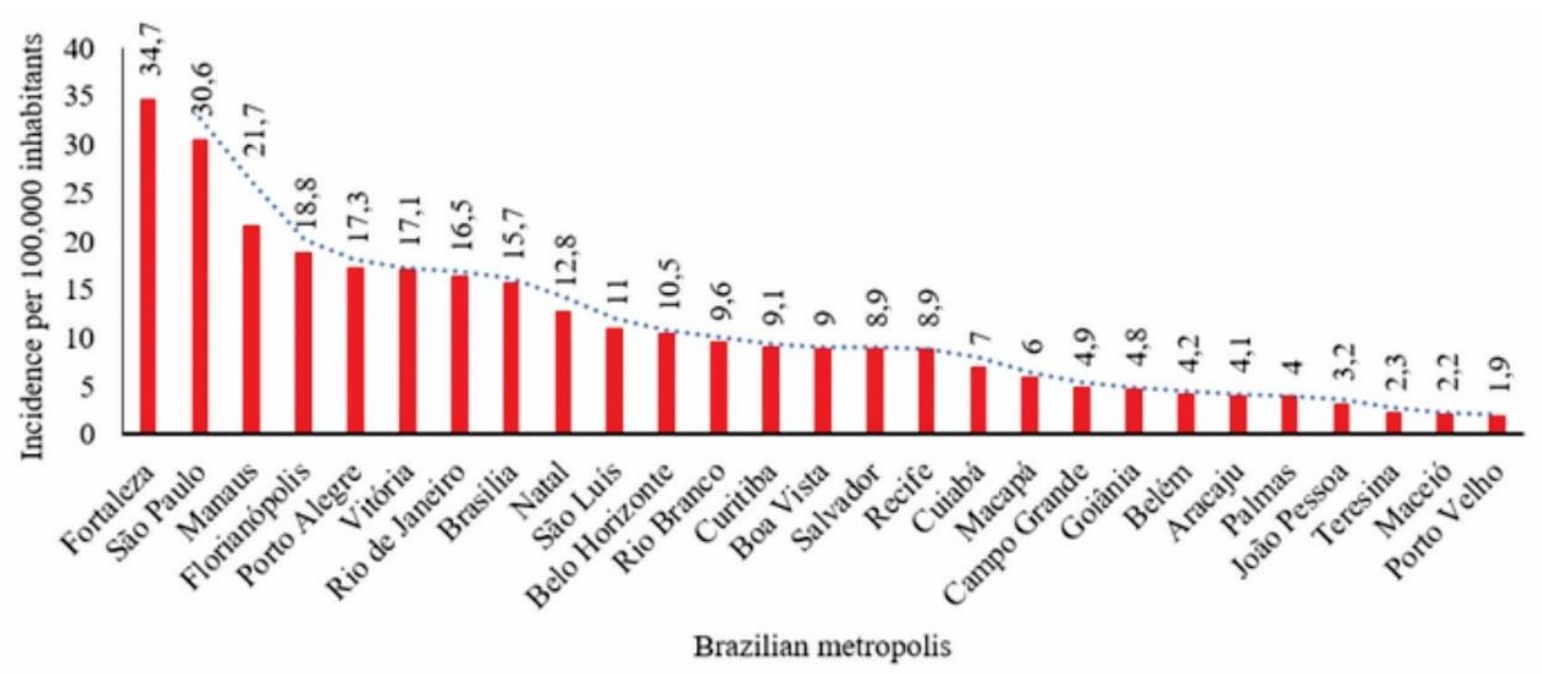

Data: Ministry of Health and IBGE (2019).

Nationally, until March 14, 2020, Fortaleza was responsible for $8 \%$ of all cases recorded in Brazil, and regionally, for $38.5 \%$ of all cases and $25.2 \%$ of the deaths in the country's northeast. In the state scenario, it is responsible for $86.5 \%$ of all confirmed cases and $67 \%$ of the deaths in Ceará. In the 31 days of the pandemic in Brazil (March 15-April 14), Fortaleza has witnessed a percentage growth of $3,222 \%$, recording an average 65.5 cases per day, or 2.7 per hour.

Fortaleza's epidemic curve continues to rise
(Fig. 7). Government measures to combat the pandemic, such as social distancing and quarantine, have slowed the spread, as recorded by the Department of Physics at the Federal University of Ceará on April 9, 2020, and yet, until April 14, 2020, COVID-19 cases had already spatially distributed in 114 of the 121 neighborhoods of Fortaleza. From the information highlighted above, the universalization of cases by neighborhood is just a matter of time. 
Figure. 7. Epidemic curve of COVID-19 in Fortaleza.

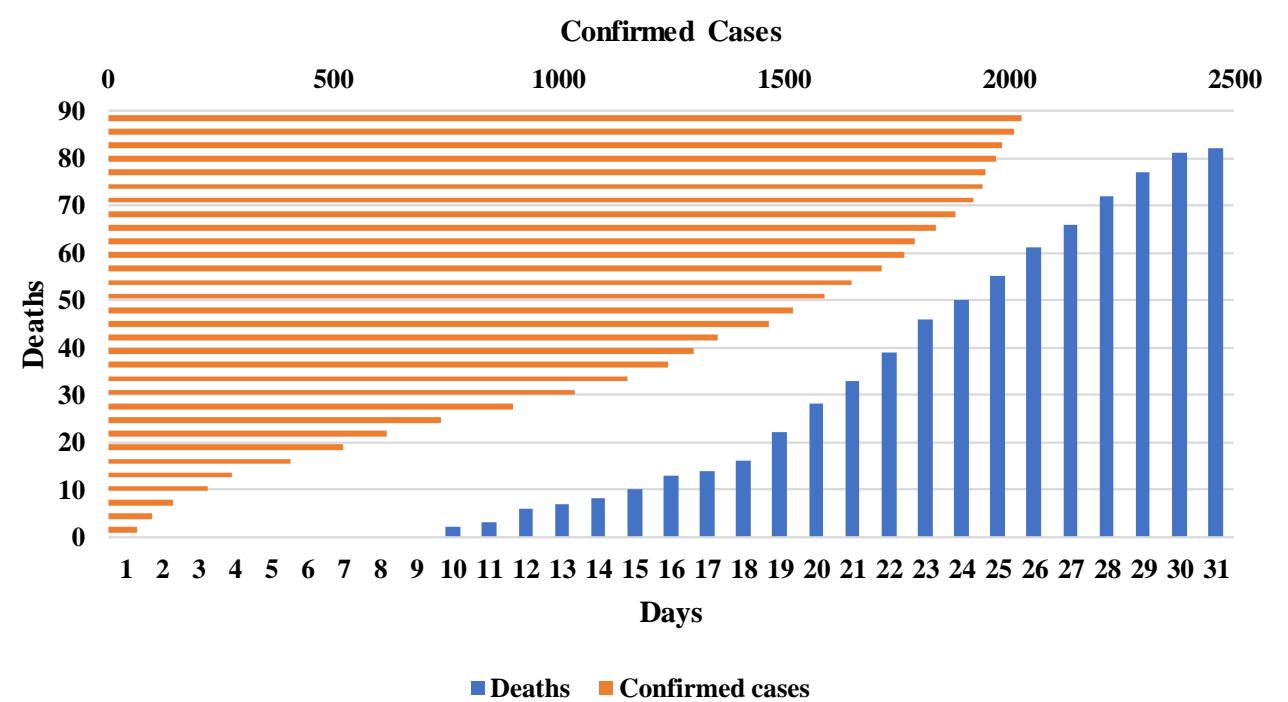

Data: SESA epidemiological bulletins.

The most affected neighborhoods in Fortaleza in the first three weeks (March 15April 4) of the outbreak in the city were those located in Regional Secretariat II. This territory comprises high-income neighborhoods, such as Meireles (166 cases), as well as low-income ones, such as Vicente Pinzon (22 cases) (Fig. 8). In terms of the magnitude of the number of cases, Meireles, identified as the neighborhood from where SARS-CoV-2 started circulating in the city, had already recorded more cases than some states (Paraíba [136]; Piauí [58]; and Sergipe [45]) until April 14, 2020.

Figure. 8. Neighborhoods with more confirmed cases of COVID-19 in Fortaleza until April 14, 2020, with identification of inhabitants' average monthly income.

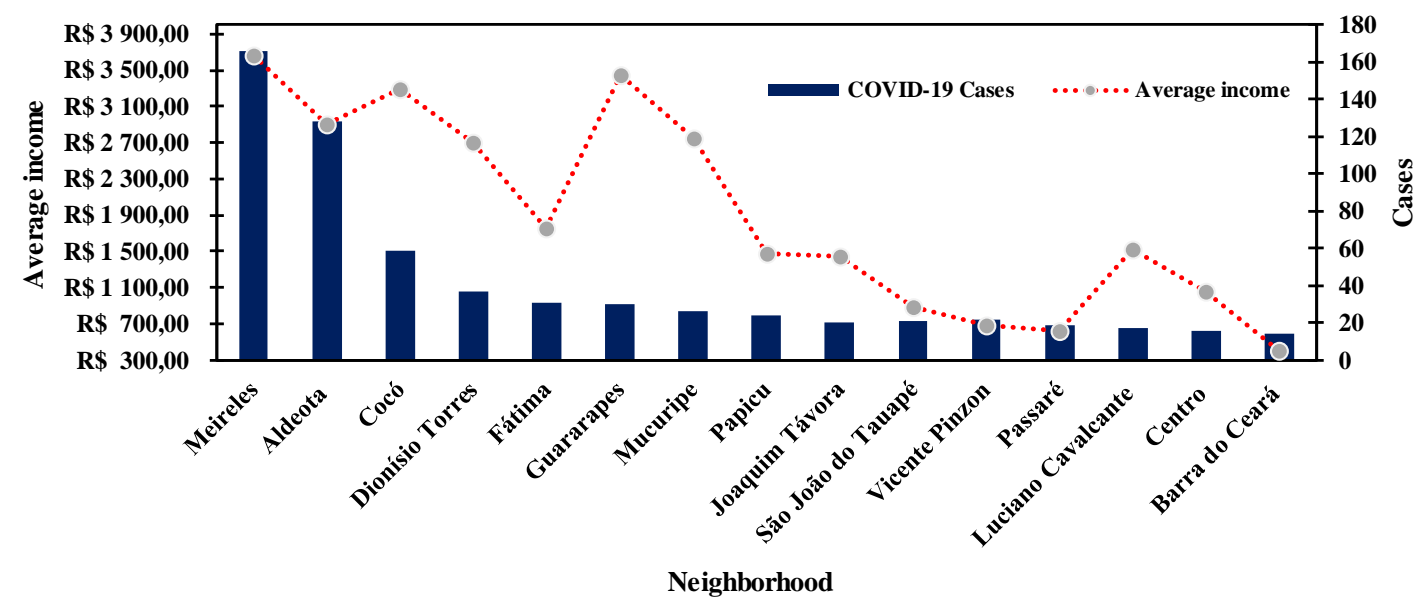

Source: SMS and IBGE (2010).

As mentioned, more cases are distributed in Regional II neighborhoods having the highest HDI in the municipality-Meireles, Mucuripe, Aldeota, Cocó and Guararapes. However, by the fourth week (April 5) of the outbreak in Fortaleza, the contagion spread to the most socially vulnerable neighborhoods, which have inadequate essential services (e.g. healthcare, and sewage collection and treatment). HDI and average income are representative of territories with populations that fall below the poverty line, according to the values indicated in the report on the Synthesis of Social Indicators of the IBGE for the year 2019 .

The spread of the contagion to other regions of the city is probably a result of the high population density in Regional I, III, and V neighborhoods, which led to increased movement of people from bus terminals and subway stations to Regional II and SERCEFOR 
neighborhoods, once they realized their centrality in the urban dynamics of Fortaleza
(SILVA; GONÇALVES, 2012; SILVA; MUNIZ, 2020) (Fig. 9).

Figure. 9. Maps showing the distribution of urban water supply and transport services, and spatialization of the number of confirmed cases and deaths due to COVID-19 in Fortaleza until April

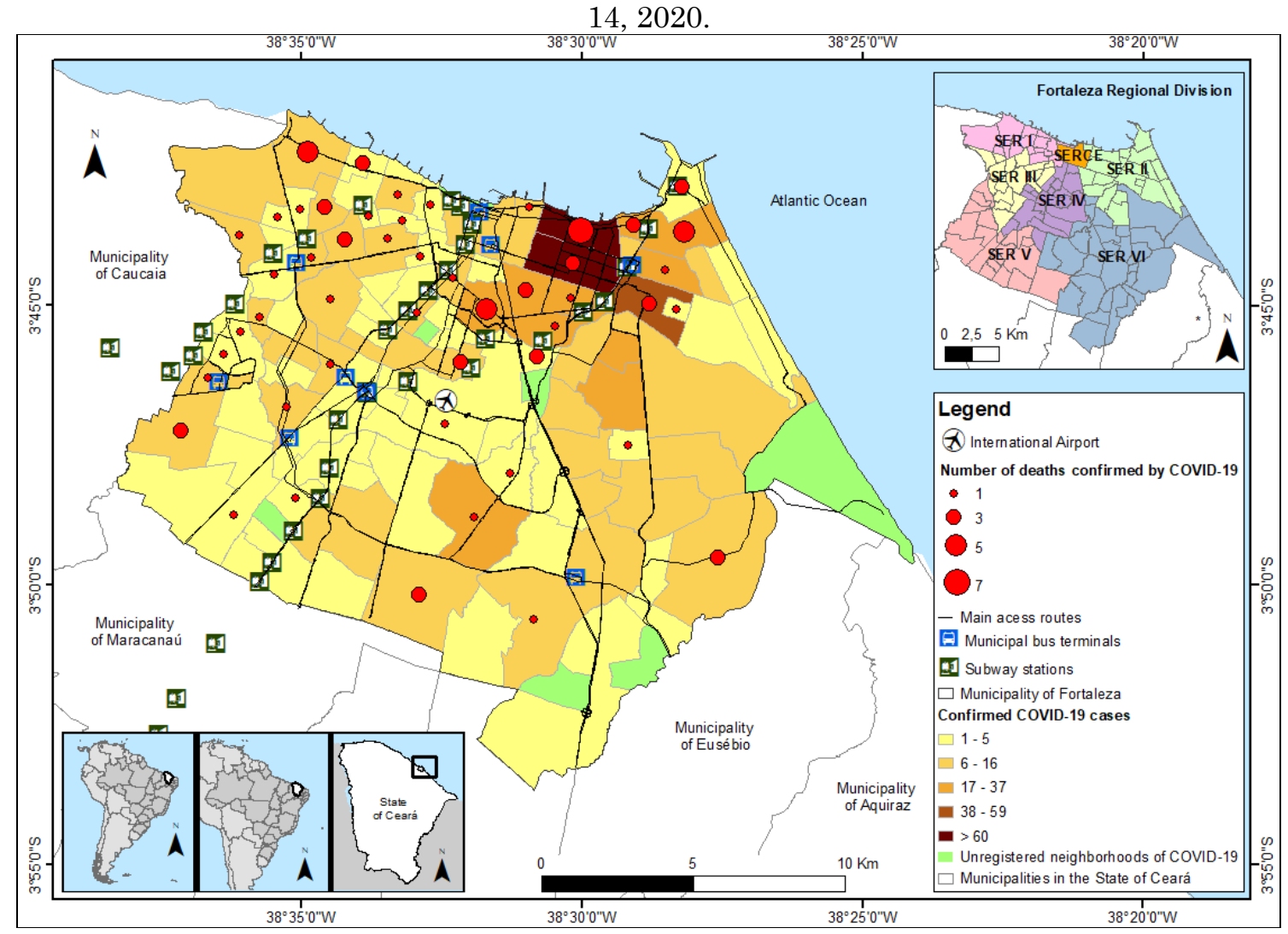

Data Source: IPLANFOR, 2020, SESA epidemiological bulletins.

Regional II and VI neighborhoods have lower demographic densities and relatively fewer precarious settlements compared with others, and yet, they have a greater concentration of COVID-19 cases. This is a situation that is in contrast with the global pandemic scenario, as public health specialists in Italy, Spain, the US, and Brazil have said that proximity between people is the main factor in the transmission of the disease.

\section{SOCIAL VULNERABILITY AND \\ PERCEIVED RISK OF COVID-19 IN \\ FORTALEZA'S PRECARIOUS SETTLEMENTS}

The flow of people in the territories of large metropolises takes center stage for public health agencies, considering the acceleration in the contagion's intra-urban circulation, population density, urban infrastructure, and healthcare, factors Fortaleza has already fared poorly in since April 14, 2020, according to the Secretary of Health's report in the local media.

Concerns related to the territories' conditions, expressed through the structures of opportunities, are recognized (KAZTMAN; FILGUEIRA 2006; PENNA; FERREIRA, 2014) which embody the diverse picture of social vulnerability in Fortaleza. These structures are related to each other as they facilitate access to other opportunities, goods, and services offered by the state, market, and society (PENNA; FERREIRA, 2014).

In Fortaleza, the peripheral areas are among the most susceptible to the uncontrolled acceleration in the transmission of COVID-19, given the structural, social, and economic deficiencies arising from the historical process of production of the urban space that has mitigated social inequalities. The spatial processes in the city, therefore, reflect the social processes that were established, leading to a spatial dynamic that affects the forms of socio-spatial segregation (SOUZA, 2006).

In this context, the HDI by neighborhood of 
Fortaleza shows the inequalities and social vulnerability of its different territories. Most of its regional districts in the west, south, and southwest have precarious settlements, such as Pirambu, Barra do Ceará, Moura Brazil, Vicente Pinzon, Lagamar, and Serviluz among others. In general, these are territories occupied by lowincome populations and without easy access to essential public services, which makes them socially vulnerable to the pandemic.

These conditions are associated with population concentration and inhabited area, which, in large numbers, represent precarious housing lots that are less than $25 \mathrm{~m}^{2}$ in size (Table 2). In such a case, extreme poverty may rise due to the rapid spread of COVID-19 in Fortaleza's precarious settlements.

Table 2. Population concentration and precarious settlements up to $25 \mathrm{~m}^{2}$ in Fortaleza.

\begin{tabular}{cccc}
\hline SER & Lot $<\mathbf{2 5 m}^{\mathbf{2}}$ & $\begin{array}{c}\text { Relative } \\
\text { concentration in the } \\
\text { municipality }\end{array}$ & $\begin{array}{c}\text { Demographic density } \\
\text { (inhab. } \mathbf{k m}^{\mathbf{2}} \text { ) }\end{array}$ \\
\hline SERCE & 171 & $8,7 \%$ & 5.762 \\
\hline I & 506 & $25,7 \%$ & 16.703 \\
\hline II & 258 & $13,1 \%$ & 8.432 \\
\hline III & 385 & $19,5 \%$ & 13.758 \\
\hline IV & 356 & $18 \%$ & 10.975 \\
\hline V & 145 & $7,3 \%$ & 11.293 \\
\hline VI & 152 & $7,7 \%$ & 5.919 \\
\hline TOTAL & $\mathbf{1 . 9 7 3}$ & $\mathbf{1 0 0} \%$ & - \\
\hline
\end{tabular}

Source: FORTALEZA (2020e).

Figure 10 shows the territorialization of COVID-19 cases in Fortaleza, especially their distribution in neighborhoods not sufficiently backed by public policies of social development in the city. According to Lima; Santos (2018), precarious settlements are territories of the lowest-income social groups in Fortaleza. In other words, they are socially vulnerable areas representative of the socioeconomic and demographic assets (e.g. urban infrastructure, human capital, and income and work) that affect daily living. Studies show that in disaster events, such as the ongoing pandemic, such territories are more likely to be hugely affected (SCHMIDTLEIN et al., 2008; FLANAGAN et al., 2011; DECAPPRIO, 2020).

Based on the settlements' demographic aspects, 243,170 properties housing 352,597 families were identified, totaling a population of 964,562 living in precarious and socially vulnerable conditions, that is, conditions conducive to a contagion with high lethality.
Lima; Santos (2018) had grouped precarious settlements, based on the Local Housing Plan of Social Interest in Fortaleza, into tenements, irregular subdivisions, degraded housing developments, joint efforts, and favelas (Fig. 11).

The results of this study, when compared to those of the investigations of Magalhães et al., (2019) and Barreira Filho and Pontes (2012), indicate that there are spatial correlations of the impacts of Covid-19 with that of other contagious diseases in Fortaleza. The spatialization of the cited cases, if overlapped with areas of greater environmental fragility and social vulnerability, as highlighted in Santos (2015) and Lima and Santos (2018), provide evidence that there is an unequal distribution of the population in the territory. This differential spatialization of the population shows that in the most vulnerable areas, the risks are combined, exacerbating the situations propitious to the occurrence of calamities. 
Figure. 10. Maps of the Human Development Index by neighborhoods in Fortaleza and precarious

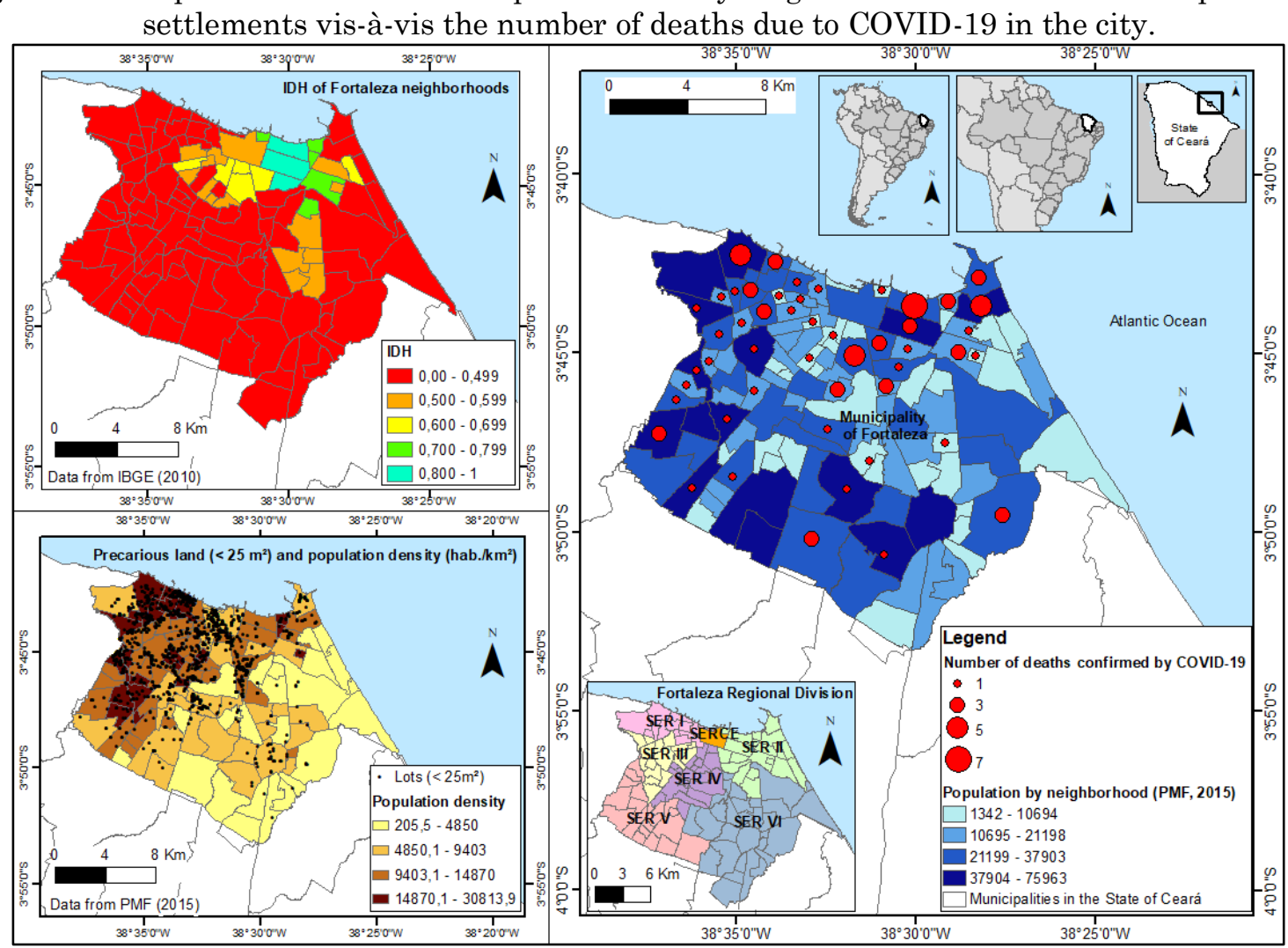

Data Source: IPLANFOR, 2020 and SESA epidemiological bulletins.

Figure. 11. Map of the socially vulnerable territories in Fortaleza's precarious settlements.

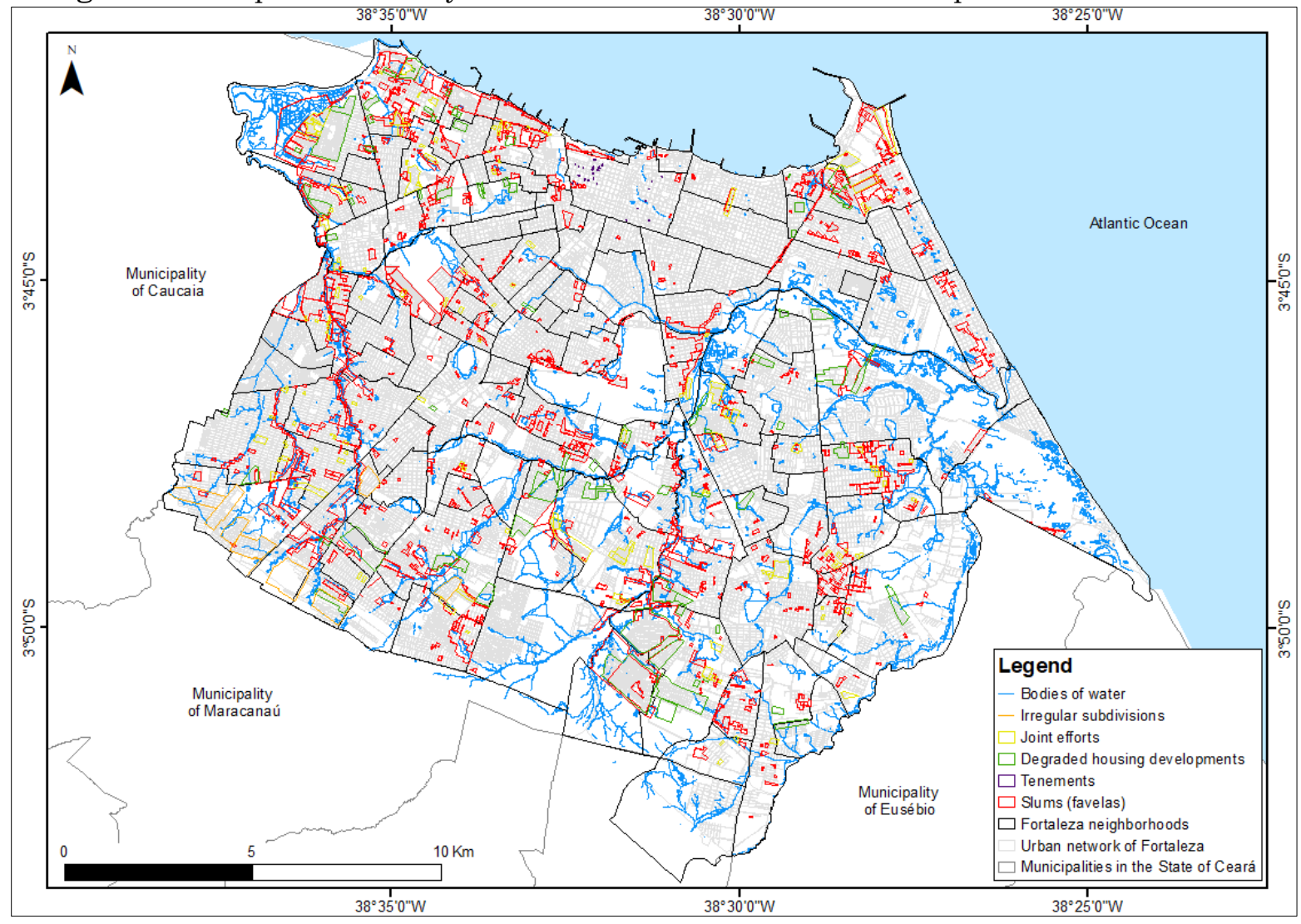

Source: LIMA; SANTOS (2018). 
MEASURES ADOPTED TO COMBAT THE PANDEMIC IN FORTALEZA

In light of these observations, intervention measures have been put in place to combat the spread of SARS-CoV-2, with emphasis on the implementation of social distancing, promoted by the state. The repercussions have been wideranging-favorable with respect to controlling the spread of the virus (OPOVO, 2020a) and unfavorable with respect to the economic scenario (mainly informal and small businesses) and social behavior of the population (OPOVO, 2020b). In summary, the measures can be classified according to their purpose of social / economic protection or public health. Implemented at the federal, state, and municipal levels until the second week of April 2020, they are listed in Table 3.

The measures assumed the role of transitional interventions with a focus on guarantee of minimum income, food supply, income generation, inputs for health professionals, and consolidation of social distancing. In response, Fortaleza demonstrated an abrupt change in the functioning of essential services, immersing itself in a state of stagnant social circulation.

Among the service limitations identified as crucial for slowing the spread of COVID-19 in the state is restriction on international flights, considering the huge number of passengers increased further courtesy Fortaleza the air hub. It was on March 15, 2020 that the flow of flights and passengers in and through Ceará attracted the attention of the state government (EL PAIS, 2020).

As an immediate measure, the state public power put in a request for the suspension of international flights to and from Fortaleza with the federal regulatory bodies (National Civil Aviation Agency and National Health Surveillance Agency [ANVISA]). However, this was only implemented after the publication of Ordinance No. 126 of March 19, 2020-it temporarily restricts the entry of foreigners from countries recommended by ANVISA. This ambit was expanded through a judicial decision to include all countries having confirmed COVID19 cases, but later revoked at the request of the Attorney General's Office.

After the implementation of the measures, the population's discontent with the urban economy has manifested through small and micro companies, and street vendors and domestic services within the formal and informal markets. In Fortaleza, the informal sector comprises a considerable portion of the population residing in areas of high social vulnerability and commuting for work daily to neighborhoods with better structures of opportunities.

In addition to the existing limitations due to the lack of public sanitation services, garbage collection, and access to public health equipment, which are basic essential facilities, social segregation has shown its most perverse face following the enforcement of social distancing to combat COVID-19. Thus, the necessary interventions by the public authorities and collective awareness of the collaborating population have been forced onto the people and communities most vulnerable to the social and economic impacts of the pandemic in Fortaleza.

\section{FINAL CONSIDERATIONS}

The data on confirmed cases used in this research are available publicly and updated daily on government platforms. The rate of increase in confirmed cases is changing by the hour, transforming the analyses into information relevant for the strategic planning of measures to deal with the pandemic.

We focus only on the first month of the COVID-19 pandemic in Ceará, which does not allow conclusive analyses of the actual rate of increase in cases, let alone future prognosis. However, the information and analyses presented herein allow us to detect how, when, and where COVID-19 has had the greatest territorial impact in Ceará.

The pandemic is worsening rapidly in the state, which could lead to a bigger tragedy, given the limited number of public beds in intensive care units and territorialization of SARS-CoV-2 in the poorest regions and most deprived service areas such as basic healthcare (health, and sewage collection and treatment).

Fortaleza is directly responsible for the pace of rise in the number of COVID-19 cases in Ceará, having a major role in spreading the contagion throughout the state. It is also clear that its air centrality in Brazil contributed to the first cases, due to imported transmission.

The contagion in Fortaleza spread from highincome neighborhoods toward peripheral ones where socially vulnerable groups are concentrated. Low-income social groups have been the most affected, as they inhabit densely populated communities that are deficient in terms of urbanization and habitability, thus becoming most vulnerable to the local impact of the pandemic. 
Table 3. Summary of the measures adopted by the federal, state, and municipal authorities to slow the spread of COVID-19.

\begin{tabular}{|c|c|c|c|c|c|}
\hline Category & Summary of the implemented measure & Date & $\begin{array}{l}\text { Legal } \\
\text { instrument }\end{array}$ & Scope & Validity \\
\hline \multirow{14}{*}{ Public health } & $\begin{array}{l}\text { Declaration of a public health emergency and control measures } \\
\text { to combat COVID-19 at the federal level }\end{array}$ & $2 / 3 / 2020$ & $\begin{array}{l}\text { Ordinance No. } 188 \\
\text { / } 2020 \text { Ministry of } \\
\text { Health }\end{array}$ & Federal & - \\
\hline & $\begin{array}{l}\text { Implementation of measures to face and contain the COVID-19 } \\
\text { outbreak across the country }\end{array}$ & $2 / 06 / 2020$ & $\begin{array}{l}\text { Law No. } 13,979 \text { / } \\
2020\end{array}$ & Federal & $\begin{array}{l}\text { Period of state of } \\
\text { emergency }\end{array}$ \\
\hline & $\begin{array}{l}\text { Worldwide alert for countries to take intensive actions to contain } \\
\text { the spread of SARS-CoV-2 }\end{array}$ & $3 / 11 / 2020$ & $\begin{array}{l}\text { World Health } \\
\text { Organization }\end{array}$ & $\begin{array}{l}\text { Worldwid } \\
\text { e }\end{array}$ & 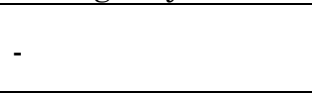 \\
\hline & $\begin{array}{l}\text { Creation of a multisectoral committee to tackle the spread of } \\
\text { COVID-19 in Ceará }\end{array}$ & $3 / 13 / 2020$ & $\begin{array}{l}\text { Decree } \mathrm{n}^{\circ} 33.509 / \\
2020\end{array}$ & State & - \\
\hline & $\begin{array}{l}\text { Decreeing a public health emergency and implementing (mild) } \\
\text { measures to contain the spread of COVID-19 in Ceará }\end{array}$ & $3 / 16 / 2020$ & $\begin{array}{l}\text { Decree } \mathrm{n}^{\circ} 33.510 / \\
2020\end{array}$ & State & - \\
\hline & $\begin{array}{l}\text { Decreeing an emergency situation and articulating measures to } \\
\text { combat the spread of SARS-CoV-2 in Fortaleza }\end{array}$ & $3 / 17 / 2020$ & $\begin{array}{l}\text { Decree } n^{\circ} 14.611 / \\
2020\end{array}$ & $\begin{array}{l}\text { Municipa } \\
\text { l }\end{array}$ & - \\
\hline & Decreeing a state of public calamity across the national territory & $3 / 20 / 2020$ & $\begin{array}{l}\text { Legislative Decree } \\
\text { No. } 6 / 2020\end{array}$ & Federal & - \\
\hline & $\begin{array}{l}\text { Guaranteeing full-time cemeteries and funeral services, and } \\
\text { necessary works in hospitals }\end{array}$ & $3 / 23 / 2020$ & $\begin{array}{l}\text { Decree } \mathrm{n}^{\circ} 33.523 / \\
2020\end{array}$ & State & - \\
\hline & $\begin{array}{l}\text { Allowing students pursuing courses in the health area to } \\
\text { continue their studies, to fight COVID-19 }\end{array}$ & $3 / 23 / 2020$ & $\begin{array}{l}\text { Ordinance No. } 492 \\
\text { / } 2020\end{array}$ & Federal & - \\
\hline & $\begin{array}{l}\text { Extension of measures to restrict activities in order to intensify } \\
\text { social distancing }\end{array}$ & $3 / 28 / 2020$ & $\begin{array}{l}\text { Decree } \mathrm{n}^{\circ} 33.530 / \\
2020\end{array}$ & State & $6 / 4 / 2020$ \\
\hline & $\begin{array}{l}\text { Decreeing a state of public calamity in Fortaleza as part of the } \\
\text { fight against COVID - } 19\end{array}$ & $3 / 31 / 2020$ & $\begin{array}{l}\text { Law No. } 10,995 / \\
2020\end{array}$ & $\begin{array}{l}\text { Municipa } \\
1\end{array}$ & - \\
\hline & $\begin{array}{l}\text { Establishing the Center for Public Health Emergency } \\
\text { Operations for coping with COVID-19(COE) }\end{array}$ & $1 / 4 / 2020$ & $\begin{array}{l}\text { Ordinance No. } 167 \\
\text { / } 2020 \text { SMS }\end{array}$ & $\begin{array}{l}\text { Municipa } \\
1\end{array}$ & - \\
\hline & $\begin{array}{l}\text { Decreeing a state of public calamity in the state as part of the } \\
\text { fight against COVID-19 in Ceará }\end{array}$ & $4 / 3 / 2020$ & $\begin{array}{l}\text { Legislative Decree } \\
\mathrm{n}^{\circ} 543 / 2020\end{array}$ & State & $12 / 31 / 2020$ \\
\hline & $\begin{array}{l}\text { Extension of the optional point as a way of reducing } \\
\text { agglomerations in the municipal public service }\end{array}$ & $4 / 5 / 2020$ & $\begin{array}{l}\text { Decree } \mathrm{n}^{\circ} 14.634 / \\
2020\end{array}$ & $\begin{array}{l}\text { Municipa } \\
\text { l }\end{array}$ & $4 / 20 / 2020$ \\
\hline
\end{tabular}




\begin{tabular}{|c|c|c|c|c|c|}
\hline & $\begin{array}{l}\text { Revocation of the flexibility actions in social distancing after } \\
\text { consulting the state health authorities }\end{array}$ & $4 / 4 / 2020$ & $\begin{array}{l}\text { Decree } \mathrm{n}^{\circ} 33.537 / \\
2020\end{array}$ & State & $4 / 20 / 2020$ \\
\hline & $\begin{array}{l}\text { Anticipating the graduation of medicine, nursing, pharmacy, and } \\
\text { physiotherapy students to join the fight against COVID-19 }\end{array}$ & $4 / 6 / 2020$ & $\begin{array}{l}\text { Ordinance No. } 374 \\
/ 2020\end{array}$ & Federal & - \\
\hline & $\begin{array}{l}\text { Decreeing a state of emergency in } 102 \text { municipalities in Ceará as } \\
\text { part of combating the spread of SARS-CoV-2 }\end{array}$ & $4 / 8 / 2020$ & $\begin{array}{l}\text { Legislative Decree } \\
\mathrm{n}^{\circ} 545 / 2020\end{array}$ & State & $12 / 31 / 2020$ \\
\hline \multirow{11}{*}{$\begin{array}{l}\text { Social } \\
\text { protection } \\
\text { Economy }\end{array}$} & $\begin{array}{l}\text { Making the measures implemented via Decree } \mathrm{n}^{\circ} 33.510 / 2020 \\
\text { more restrictive, with the objective of increasing social } \\
\text { distancing }\end{array}$ & $3 / 19 / 2020$ & $\begin{array}{l}\text { Decree } \mathrm{n}^{\circ} 33.519 / \\
2020\end{array}$ & State & $3 / 29 / 2020$ \\
\hline & $\begin{array}{l}\text { Implementing a measure to reduce the financial impact of social } \\
\text { distancing on micro and small businesses }\end{array}$ & $3 / 19 / 2020$ & $\begin{array}{l}\text { Resolution No. } 152 \\
\text { / } 2020 \text { CGSN }\end{array}$ & Federal & $12 / 21 / 2020$ \\
\hline & $\begin{array}{l}\text { Enforcement of the exceptional and temporary restriction on the } \\
\text { entry of foreigners in Brazil from the countries recommended by } \\
\text { the National Health Surveillance Agency (ANVISA) }\end{array}$ & $3 / 19 / 2020$ & $\begin{array}{l}\text { Ordinance No. } 126 \\
\text { / } 2020\end{array}$ & Federal & - \\
\hline & $\begin{array}{l}\text { Extension of the suspension of school activities, and ensuring the } \\
\text { provision of basic facilities, such as accommodation and food, for } \\
\text { the continuity of essential services }\end{array}$ & $3 / 30 / 2020$ & $\begin{array}{l}\text { Decree } \mathrm{n}^{\circ} 33.532 / \\
2020\end{array}$ & State & - \\
\hline & $\begin{array}{l}\text { Provision of emergency aid of } \mathrm{R} \$ 600 \text { for low-income families } \\
\text { impacted by the measures to combat COVID- } 19\end{array}$ & $4 / 1 / 2020$ & $\begin{array}{l}\text { Provisional } \\
\text { Measure } 936 \quad / \\
2020\end{array}$ & Federal & $\begin{array}{l}\text { Period of state of } \\
\text { emergency }\end{array}$ \\
\hline & $\begin{array}{l}\text { Ensuring state public resource contingencies, not including the } \\
\text { Health Department }\end{array}$ & $4 / 1 / 2020$ & $\begin{array}{l}\text { Resolution No. } 07 / \\
2020\end{array}$ & State & $\begin{array}{l}\text { Period of state of } \\
\text { emergency }\end{array}$ \\
\hline & $\begin{array}{l}\text { Guaranteeing payment for water, and of sewage and electricity } \\
\text { bills for three months for low-income families }\end{array}$ & $4 / 3 / 2020$ & $\begin{array}{l}\text { Law No. } 17,196 / \\
2020\end{array}$ & State & 90 days \\
\hline & $\begin{array}{l}\text { Encouraging the creation of cultural content by local artists on } \\
\text { digital platforms, as a way of supplementing their income }\end{array}$ & $4 / 3 / 2020$ & \begin{tabular}{lll|} 
Notice & 1 \\
SECULT & & - \\
\end{tabular} & State & May to June 2020 \\
\hline & $\begin{array}{l}\begin{array}{l}\text { Promotion of the production of facial fabric } \\
\text { independent } \\
\text { sewing } \\
\text { microentrepreneurs, and microenterprises }\end{array} \\
\text { professionals, } \\
\text { individual }\end{array}$ & $4 / 5 / 2020$ & Notice 5336 - SDE & $\begin{array}{l}\text { Municipa } \\
1\end{array}$ & 10 days \\
\hline & $\begin{array}{l}\text { Establishing a partnership with an institution for the care of } \\
\text { children and adolescents suspected of having COVID-19 }\end{array}$ & $4 / 6 / 2020$ & \begin{tabular}{lll|} 
Resolution $34 \quad /$ \\
2020
\end{tabular} & $\begin{array}{l}\text { Municipa } \\
1\end{array}$ & - \\
\hline & $\begin{array}{l}\text { Implementation of measures to reduce expenses, vis-à-vis } \\
\text { municipal taxes, for microenterprises, small companies, and MEI }\end{array}$ & $4 / 7 / 2020$ & $\begin{array}{l}\text { Decree } \mathrm{n}^{\circ} 14.637 / \\
2020\end{array}$ & $\begin{array}{l}\text { Municipa } \\
1\end{array}$ & 60 to 90 days \\
\hline
\end{tabular}




\begin{tabular}{|c|c|c|c|c|c|}
\hline & $\begin{array}{l}\text { Determining the distribution of foodstuff to students in } \\
\text { vulnerable situations in the Municipal Education Network of } \\
\text { Fortaleza }\end{array}$ & $4 / 7 / 2020$ & $\begin{array}{l}\text { Ordinance } \quad \text { No. } \\
0156 / 2020\end{array}$ & $\begin{array}{l}\text { Municipa } \\
1\end{array}$ & - \\
\hline & $\begin{array}{l}\text { Dealing with the postponement of appointments, promotions, } \\
\text { and recruitment of civil servants until 2021, not including the } \\
\text { Health Department }\end{array}$ & $4 / 7 / 2020$ & $\begin{array}{l}\text { Resolution } 01 \text { / } \\
2021-\text { COGERF }\end{array}$ & State & $31 / 12 / 2020$ \\
\hline & $\begin{array}{l}\text { Implementing the distribution of kitchen gas cylinders to } \\
\text { families in socially vulnerable conditions }\end{array}$ & $4 / 8 / 2020$ & $\begin{array}{l}\text { Law No. } 17,202 / \\
2020\end{array}$ & State & - \\
\hline & $\begin{array}{l}\text { Implementation of a reduction in electricity tariff for users with } \\
\text { a consumption share lower than or equal to } 220 \mathrm{kWh} / \text { month }\end{array}$ & $4 / 8 / 2020$ & $\begin{array}{l}\text { Provisional } \\
\text { Measure No. } 950\end{array}$ & Federal & $\begin{array}{l}\text { April } 1 \text { to June } \\
30,2020\end{array}$ \\
\hline & $\begin{array}{l}\text { Provision of a food card worth } \mathrm{R} \$ 80 \text { for complementary food for } \\
\text { families of students in the state public school system }\end{array}$ & $4 / 9 / 2020$ & $\begin{array}{l}\text { Decree } n^{0} 33.541 / \\
2020\end{array}$ & State & - \\
\hline
\end{tabular}


Considering the published data of confirmed cases and deaths as a result of COVID-19 through August 11, 2020, almost four months after the data analysis deadline of this study, it is possible to observe that, in the case of Brazil, the numbers of confirmed cases jumped from 25,262 to $2,862,761$, which is equivalent to an increase of $11,232 \%$. The number of deaths exceeded 100,000 , with an increase of $6,543 \%$. In the case of the State of Ceará, the number of confirmed cases increased by 9,131\% between April 15, 2020, and August 11, 2020. The number of deaths, for the same period, increased by $4,549 \%$. In both scenarios, there was a growing territorialization of COVID-19 in the most peripheral areas of the Brazilian states. In the case of Fortaleza, the observed trend of growth of cases in the most socially vulnerable areas was confirmed throughout the month of May 2020, consolidating itself throughout the month of June 2020 in the so-called informal city, where precarious settlements and the lack of sanitary conditions are characteristics that have aggravated other epidemiological outbreaks such as dengue, chikungunya, and the Zika virus. Still in a phase with high numbers of cases and deaths, but with evident loss of speed in the registration of new cases and deaths, the Government of the State of Ceará announced the resumption of economic activities starting in June 2020, complete with technical criteria and phases of transition between the various productive sectors. After more than two months of economic reopening, the numbers of new cases of Sars-CoV-2 continue to rise in Fortaleza, with a high concentration in the number of deaths in the poorest neighborhoods of the city, as is the case of Barra do Ceará, Vila Velha, and Bom Jardim, confirming the trend observed in the first month of pandemic of the new Coronavirus in Fortaleza, evidenced from the identification of urban precariousness of the city. Finally, the informal settlements territorialized in Fortaleza, recognized as socially vulnerable, are the areas that have been most affected by this pandemic.

Given our results and all that has been analyzed so far, the spread of COVID-19 should be given greater attention, not only by the public authorities at the three levels of power in a unified manner but also by the citizens through better awareness, to stabilize the situation at the earliest.

\section{ACKNOWLEDGMENTS}

The first author thanks the $\mathrm{CNPq}$ grant $\mathrm{PQ}$ 310246/2019-9. The authors also would like to thank: The Ministry of Health of the Federal Government, the Ceará State Health Department, Fortaleza Municipality Health Department by the availability of data for this research. They also thank the support of the Geography's Postgraduate Programs of the Ceará State University of Ceará - UECE (PROPGEO, Universidade Estadual do Ceará UECE) and Federal University of Ceará (PPGeografia, Universidade Federal do Ceará UFC).

\section{REFERENCES}

BRASIL. Ministério da Saúde. Boletins Epidemiológicos. 2020. Available in: $<$ https://www.saude.gov.br/boletinsepidemiologicos/> Acessed: April 14, 2020. (2020a)

Ministério da Saúde. Boletim Epidemiológico 08: Especial: Doença pelo Coronavírus 2019 Semana Epidemiológica 15 (05-10/04). Available in: $<$ https://www.saude.gov.br/images/pdf/2020/Ap ril/06/2020-04-06-BE7-Boletim-Especial-doCOE-Atualizacao-da-Avaliacao-de-Risco.pdf $>$ Acessed: April 06, 2020. (2020b).

BARREIRA FILHO, E. B.; PONTES, J. R. S. A inserção da vigilância em saúde ambiental no Sistema Único de Saúde. Revista Brasileira em Promoção da Saúde (Online), v. 25, p. 1-2, 2012. https://doi.org/10.5020/18061230.2012.p1

CARTER, J; SAUNDERS, V. Virology, principles and applications. New York, NY: Wiley, 2007.

CEARÁ. Decreto $\mathrm{n}^{\circ} 33.510$, de 16 de março de 2020. Available in: <http://imagens.seplag.ce.gov.br/PDF/2020031 6/do20200316p01.pdf>. Acessed: April 13, 2020. (2020a).

2020. Decreto $\mathbf{n}^{\mathbf{0}}$ 33.519, de $\mathbf{1 9}$ de março de
Available $\begin{aligned} & \text { in: } \\ & \text { <http://imagens.seplag.ce.gov.br/PDF/2020031 } \\ & \text { 9/do20200319p01.pdf>. Acessed: April 13, } \\ & \text { 2020. (2020b). }\end{aligned}$

Transparência da saúde do Ceará. 2020. Available in: $<$ https://indicadores.integrasus.saude.ce.gov.br /indicadores/indicadores-

coronavirus/coronavirus-ceara/> Acessed: April 14, 2020. (2020c).

COELHO, F. C.; LANA, R. M.; CRUZ, O. G.; CODECO, C. T.; VILLELA, D.; BASTOS, L. 
S.; PIONTTI, A. P. Y.; DAVIS, J. T.; VESPIGNANI, A.; GOMES, M. F. C. Assessing the potential impact of COVID-19 in Brazil: Mobility, Morbidity and the burden on the Health Care System. MedRxiv, v. xx, p. xx-xx, 2020 .

https://doi.org/10.1101/2020.03.19.20039131

DECAPPRIO, D.; GARTNER, J. A.; MCCALL, C. J.; BURGESS, T.; KOTHARI, S., SHAAYAAN, S. Building a COVID-19 Vulnerability Index. MedRxiv, v. $\quad \mathrm{xx}, \quad$ p. $1-9,2020$. https://doi.org/10.1101/2020.03.16.20036723

EL PAIS. Fortaleza lidera taxa de novos casos de Coronavírus nas capitais e Ceará já requisita leitos de hospitais privados. 2020. Available in: <https://brasil.elpais.com/sociedade/2020-0409/fortaleza-lidera-taxa-de-novos-casos-decoronavirus-nas-capitais-e-ceara-ja-requisitaleitos-de-hospitais-privados.html/>. Acessed: April 09, 2020.

FISMAN, D.; TUITE, A. R. N. G, V.; REES, E. Estimation of COVID-19 outbreak size in Italy. The Lancet Infectious Diseases, v. 20, n. 5, p. 537, 2020. https://doi.org/10.1016/S14733099(20)30227-9

FLANAGAN, B. E.; GREGORY, E. W.; HALLISEY, E. J.; HEITGERD, J. L.; LEWIS, B. A Social Vulnerability Index for Disaster Management. Journal of Homeland Security and Emergency Management, v. 8, p. 1-22, 2011. http://dx.doi.org/10.2202/15477355.1792 .

FORTALEZA.Prefeitura Municipal de Fortaleza. Decreto municipal $n^{\circ} 14.498$, de 18 de setembro de 2020. Available in $<$ https://diariooficial.fortaleza.ce.gov.br/downlo addiario.php?objectId=workspace://SpacesStore /317a341a-8ee6-44d0-b8ad

$1 \mathrm{a} 9 f 1 \mathrm{cb} 25451 ; 1.0 \&$ numero $=16590 \mathrm{~s}$

>Acessed: April 13, 2020. (2020a).

- Prefeitura Municipal de Fortaleza.

Plano Municipal de Contingência para Enfrentamento da Infecção Humana pelo Novo Coronavírus SARS-CoV-2. 2020. Available in:

<https://coronavirus.fortaleza.ce.gov.br/planode-contingencia.html>. Acessed: April 11, 2020. (2020b).

.Prefeitura Municipal de Fortaleza.

Informações da Prefeitura sobre o Coronavírus. 2020. Available in: <https://coronavirus.fortaleza.ce.gov.br>.

Acessed: April 14, 2020. (2020c).

Secretaria Municipal de Saúde. Boletins Epidemiológicos. 2020. Available in: <https://coronavirus.fortaleza.ce.gov.br/boletim -epidemiologico.html>. Acessed: April 14, 2020. (2020d).

.Prefeitura Municipal de Fortaleza. Publicações do Plano Fortaleza 2040. 2020. Available in: <https://fortaleza2040.fortaleza.ce.gov.br/site/fo rtaleza-2040/publicacoes-do-projeto> Acessed: April 09, 2020. (2020e).

HSIEH, Y.; WU, T.; LIU, D.; SHAO, P.; CHANG, L.; LU, C.; LEE, C.; HUANG, F.; HUANG, L. Influenza Pandemics: past, present and future. Journal of the Formosan Medical Association, v. 105, p. 1-6, 2006. http://dx.doi.org/10.1016/s0929-6646(09)601029

IBGE - Instituto Brasileiro de Geografia e Estatística. Censo demográfico 2010: Resultados gerais da amostra. 2010. Available in: <http://www.ibge.gov. br/home/estatistica/populacao/censo2010/result ados_gerais_amostra/resultados_gerais_amostr a_tab_uf_microdados.shtm. Acessed: April, 15, 2020.

IBGE - Instituto Brasileiro de Geografia e Estatística. Censo Demográfico 2010. Sinopse do Censo e Resultados Preliminares do Universo. 2011. Rio de Janeiro: ibge. Available in <http://www.ibge.gov.br/home/presidencia/noti cias/imprensa/ppts/0000000402.pdf> Acessed: April, 15, 2020.

IBGE - Instituto Brasileiro de Geografia e Estatística. Síntese de indicadores sociais uma análise das condições de vida da população brasileira. 2019. Available in: <https://biblioteca.ibge.gov.br/visualizacao/livr os/liv101678.pdf> Acessed: April 15, 2020.

IPLANFOR - Instituto de Planejamento de Fortaleza. Plataforma de Indicadores Fortaleza 2040. Fortaleza, Ceará, 2020. Available https://observatoriodefortaleza.fortaleza.ce.gov. br/ Acessed: April, 10, 2020.

KAZTMAN, R.; FILGUEIRA, F. As normas como bem público e privado: reflexões nas fronteiras do enfoque "ativos, vulnerabilidade e estrutura de oportunidades". In: CUNHA, J. M. P. da. (Org.) Novas metrópoles paulistas: população, vulnerabilidade e segregação. Campinas: Nepo/Unicamp, 2006. p. 67-94.

KILBOURNE, E. D. Influenza Pandemics of the 20th Century. Emerging Infectious Diseases, v. $12, \quad$ p. 9-14, 2006. http://dx.doi.org/10.3201/eid1201.051254

LAYNE, S. P., MONTO, A. S., TAUBENBERGER, J. K. Pandemic Influenza: 
an inconvenient mutation. Science, v. 323, p. 1560-1561, 2009. http://dx.doi.org/10.1126/science.323.5921.1560

LIMA, J. S. Q.; SANTOS, J. O. de. Precarious settlements in a regional metropolis of northeast brazil: the case of the Fortaleza city, Ceará state. Caminhos de Geografia, v. 19, p. 289-303, 2018. http://dx.doi.org/10.14393/hygeia196719

MAGALHÃES, G. B.; ZANELLA, M. E.; SANTANA, A. P.; ALMENDRA, R. Condicionantes climáticos e socioeconômicos na espacialização da dengue em período epidêmico e pós-epidêmico na cidade de Fortaleza-CE. Confins, n. 40, p. 1-20, 2019. http://dx.doi.org/10.4000/confins.19339

MARQUES, J. M. R.; LIMA, J. S. Q.; SANTOS, J. O. Fragilidade ambiental, Vulnerabilidade social e riscos de desastres no baixo curso do Rio Maranguapinho, Fortaleza-Ceará-Brasil. Territorium, v. 27, p. 25-35, 2020. https://doi.org/10.14195/1647-7723_27-1_3

MILLS, C. E.; ROBINS, J. M.; LIPSITCH, M. Transmissibility of 1918 pandemic influenza. Nature, v. 432, p. 904-906, 2004. http://dx.doi.org/10.1038/nature03063

O POVO. Estudo aponta eficácia em medidas de isolamento do governo Camilo. 2020a. Available in: <https://www.opovo.com.br/noticias/2020/03/25/ estudo-aponta-eficacia-em-medidas-de-

isolamento-do-governo-camilo.html>. Acessed: April 10, 2020. - $80 \%$ dos pequenos negócios do

Ceará estão economicamente vulneráveis à Covid-19. 2020b. Available in: <https://www.opovo.com.br/coronavirus/2020/0 4/02/80--dos-pequenos-negocios-do-ceara-estaoeconomicamente-vulneraveis-a-covid-19.html>. Acessed: April 10, 2020.

PENNA, N. A.; FERREIRA, I. B. Desigualdades socioespaciais e áreas de vulnerabilidades nas cidades. Mercator, v. 13, p. 25-36, 2014. https://doi.org/10.4215/RM2014.1303.0002

RODRIGUEZ-MORALES, A. J.; GALLEGO, V.; ESCALERA-ANTEZANA, J. P.; MÉNDEZ, C. A.; ZAMBRANO, L. I.; FRANCO-PAREDES, C.; SUÁREZ, J. A.; RODRIGUEZ-ENCISO, H. D.; BALBIN-RAMON, G. J.; SAVIOLARRIERA, E. COVID-19 in Latin America: the implications of the first confirmed case in brazil. Travel Medicine and Infectious Disease, v. $35, \quad$ p. $1-3, \quad 2020$. http://dx.doi.org/10.1016/j.tmaid.2020.101613

SANTOS, J. Existing relations between environmental fragility and social vulnerability in susceptibility to risk.
Mercator, v. 14, p. 75-90, 2015. https://doi.org/10.4215/RM2015.1402.0005

SCHMIDTLEIN, M. C., DEUTSCH, R. C., PIEGORSCH, W. W., CUTTER, S. L. A Sensitivity Analysis of the Social Vulnerability Index. Risk Analysis, Vol. 28, p. 1099-1114, 2008. https://doi.org/10.1111/j.15396924.2008.01072.x

SILVA, J. B. DA, GONÇALVES, T. E., Urbanização e produção da cidade: shopping centers na dinâmica de novas centralidades em Fortaleza-CE. Geosul, v. 53, p. 65-88, 2012. https://doi.org/10.5007/2177-

5230.2012v27n53p63

SILVA, J. B. DA; MUNIZ, A. M. V. Pandemia do Coronavírus no Brasil: impactos no território cearense. Espaço e Economia, n. 17, p. 1-19, 2020.

http://dx.doi.org/10.4000/espacoeconomia.10501 SOUZA, M. S. de. Segregação socioespacial em Fortaleza. In: SILVA, J. B. da; DANTAS, E. W. C.; ZANELLA, M. E.; MEIRELES, A. J. A. (org.) Litoral e Sertão: natureza e sociedade no nordeste brasileiro. Fortaleza: Expressão Gráfica, 2006. p. 135-146.

WHO. World Health Organization. Coronavirus disease (COVID-19) Pandemic. 2020a. Available in: <https://www.who.int/emergencies/diseases/no vel-coronavirus-2019> Acessed: April 14, 2020. World Health Organization. Rolling updates on coronavirus disease (COVID19). 2020b. Available in: <https://www.who.int/emergencies/diseases/no vel-coronavirus-2019/events-as-they-happen>. Acessed: March 25, 2020. 